JOURNAL OF SECURITY AND SUSTAINABILITY ISSUES

ISSN 2029-7017 print/ISSN 2029-7025 online

2019 September Volume 9 Number 1

http://doi.org/10.9770/jssi.2019.9.1(7)

Scopus

\title{
INFRASTRUCTURE SECURITY OF FORMATION AND DEVELOPMENT OF SECTORAL CORPORATE CLUSTERS
}

\author{
Natalya G. Metelenko1, Olena V. Kovalenko², Vyacheslav Makedon ${ }^{3}$, \\ Yevhenii K. Merzhynskyi ${ }^{4}$, Alla I. Rudych ${ }^{5}$ \\ ${ }^{1 *}$ Zaporizhzhya National University, Soborny Ave., 226, m. Zaporizhzhia, 69006, Ukraine \\ ${ }^{2}$ Dnipropetrovsk Scientific-Research Institute of Forensic Examinations, \\ Sichaslavskaya Naberezhna, 17, of. 361, Dnipro, 49000, Ukraine \\ ${ }^{3}$ Oles Honchar Dnipro National University, 35, Yavornitskogo str., Dnipro, 49000, Ukraine \\ ${ }^{4}$ Zaporizhzhya National University Engineering Institute, Sobornyi Avenue 226, Zaporizhzhya, 69006, Ukraine \\ ${ }^{5}$ Poltava state agrarian academy, 1/3 Skovorody str., Poltava, 36003, Ukraine \\ E-mail: ${ }^{1 *}$ koaduep@gmail.com
}

Received 14 January 2019; accepted 19 June 2019; published 30 September 2019

\begin{abstract}
The article is devoted to the problems of formation and development of sectoral corporate clusters and the infrastructure security of their formation and development in the system of the national economy. The role of the innovation infrastructure in the development of the national economy was determined, and a model was proposed for transferring the innovative product from the developer to the real economy. The main components of the production and infrastructure security of business entities when deploying an innovative business development model were outlined.
\end{abstract}

Keywords: infrastructure security, development security, innovative product, innovative infrastructure, national economy, innovative economy, sectoral corporate cluster

Reference to this paper should be made as follows: Metelenko, N.G; Kovalenko, O.V.; Makedon, V.; Merzhynskyi, Y.K.; Rudych, A.I. 2019. Infrastructure security of formation and development of sectoral corporate clusters, Journal of Security and Sustainability Issues 9(1): 77-89. http://doi.org/10.9770/jssi.2019.9.1(7)

JEL Classifications: F52, O39

\section{Introduction}

An innovation-type economy requires the creation of effective mechanisms for the security of industrial development in order to increase the overall innovation activity of sectors. In the world theory and practice of organizing territorial socio-economic development, there are many directions and concepts. The choice of specific provisions depends on the circumstances and factors affecting the national economy and its security parameters. If a country is in a crisis situation, then its economic potential is not enough to support the dynamic rates of development of all spheres at the same time. A fundamental choice of critical directions is needed, which should be emphasized to achieve the most positive effect. This specificity is most consistent with the corporate cluster approach to the formation of innovative policy and the security of business development. The cluster principle of the existence of sectors in the national economy can also become a rational tool to increase the innovation activity of industry within the economic system. The principle that is proposed, provides for the concentration of state resources in order to support not individual enterprises in the context of sector, but sectoral corporate clusters as a whole. 


\section{Literature Survey}

The issues of innovative management and the development of the innovative strategy of the national economy are quite widely represented in the works of such famous scientists as Agarwal, et al. 2017; Brem and Freitag, 2015; Chaminade, et al. 2018; Cunningham, 2014; Dobele, et al. 2015; Felt, et al. 2016; Hartley, 2015; Liu and Shi, 2017; Mansell, 2012; van Dijck et al. 2018; Von Hippel, 2005. But at the same time, the issue of corporate clusters formation, in order to develop innovative products and immediately transfer them to the real sector of the economy, does not have wide coverage and applied scientific developments. It is these components that are the basis for the study of the use of corporate and sectoral clusters to revive innovative activity in the sectors of the national economy (Monni et al., 2017).

The purpose of the article is to determine the directions of activization of the work of business entities in the direction of developing strategic programs to ensure infrastructure security and the formation of sectoral and corporate clusters for the rapid development of the real sector of the national economy. The change in the economic structure of the national economy, which is accompanied by numerous crisis phenomena in various spheres of social life, put forward the anti-crisis goals of management and development security as the main guideline. The search for ways to enhance innovation and infrastructure security, which should be based on global trends in the post-industrial development of society, is becoming topical. Among the many most acceptable strategies for socio-economic development, two groups can be distinguished: passive or extensive economic development strategies and active economic development strategies.

The first group includes the formation of peculiar system-forming "profit centers" and centers for the formation of sectoral corporate clusters in various sectors, among which metallurgical, energy, coal, machine-building industries, and logging industries can be distinguished. The basic principle on which the state policy should be built to manage the economic proportions in these sectors, is to "not interfere" with the process of systembuilding and corporate clustering of the economy around "profit centers". To do this, it is necessary to create an adequate fiscal regime for doing business, as a result the development of these sectors initiates the development of all associated and related industries and, accordingly, the development of high-tech sectors of the national economy (Antanavičius, 2017).

This group of strategies involves a minimum of government spending and a relatively short period of time for implementation. At the same time, a fairly well-functioning economy will be formed, which is achieved through targeted management of a set of sustainable corporate clusters. In this case, corporate clusters are formed around industrial complexes of the extractive sectors, by concentrating relevant production-suppliers and production-consumers and organizing common technological chains between them.

The disadvantage of a group of extensive strategies is the orientation of the country's economy towards the sale of raw materials and primary processing products and consciously technological dependence of the country on external suppliers of high-tech products and modern equipment.The group of strategies for the active development of the economy is aimed at initiating and increasing the rates of economic growth due to the industries of deep processing and high-tech industries. The main strategic focus is the development and production of competitive products primarily for end users, maximization of value added (Makedon, 2019).

The implementation of this group is much more capital-intensive, since it involves the identification and focus on the whole complex of strategic "profit centers" and corporate clustering centers, and moreover it will require a longer period of time. But the adoption of an intensive development path will make it possible to form an economy with a considerable margin of safety and a variety of strategic "profit centers." In the long run, a greater variety of successfully functioning sectoral corporate clusters will be achieved (Oganisjana, et. al. 2017; Žižka et al., 2018; Petrenko et al., 2019).

For the formation of an economy that is developing intensively, it is necessary to develop a general concept and form a set of concrete measures for its implementation. Innovative activity is one of the main internal factors 
influencing business activity in relation to the enterprise. A business activity should be understood as a set of targeted processes that ensure the pace of economic growth of an organization based on the coordinated development of its components in harmony with the external environment. It should be emphasized that innovative activity is a key factor in the strategic growth of the security level of the infrastructure providing innovative activity, that is, organizations such as innovation and technology centers (ITC).

The following factors that affect the innovative activity and security of business entities should be outlined (Akhter, 2017; Foege, et. al. 2016):

development of innovative processes: scientific, technical, organizational, financial, economic, managerial, personnel;

development of the organizational and technical potential of the enterprise, which covers the main activity, provides the production structures, service units;

product updates, which provides an increase in the level of production readiness for the production of new products and the level of organization for the implementation of innovative projects.

The force of action of these factors is reflected in the magnitude of the indicators traditionally used, which characterize the innovative activity of the enterprise, namely:

share of new products in the total output (update rate);

progressiveness ratio of the technologies used (production, information, organizational, managerial, etc.);

intensity ratio of the development of new products, which characterizes the innovation potential and the level of organizational and technical readiness of the enterprise for the industrial development of new products;

share of innovation costs in total sales.

Thus, the ITC as an element, as a rule, of the university innovation structure is also characterized by a specific type of activity factors - educational activity. This is due to the possibility of using the aggregate potential of ITC in the main direction of both the creation of new innovative products and the activities of the university educational. The concept of educational activity is to increase the various forms and methods of conducting educational activities using the potential of ITC. Moreover, we mean only those forms and methods that have positively proved themselves in practice. In the end, these types of processes lead to a steady increase in the number of graduates of various forms of education at ITC who have successfully completed training courses and have the knowledge, skills and abilities that meet the staffing needs.

\section{Methods}

Obviously, the higher the positive trends in the growth of innovative potential and innovative activity of an innovative infrastructure facility are, the less the small innovative firm needs to spend money on creating its own innovative potential, since the costliest steps of the innovative process will be realized with the potential of the innovative infrastructure facility. In other words, the growth of the innovative potential reduces the barrier to the cumulative necessary investments of a small company in the successful implementation of its own innovative project. In this regard, it is advisable to use ITC, which act as "points of growth" of the innovative economy (Kraus, 2016). Such approach will reduce the cost of implementing innovative strategies for economic development, since it is realistic to recreate the innovative activity of industries by combining human, intellectual and technological potential based on its local corporate clustering around effectively functioning infrastructure facilities. The feasibility of building such an innovative system has been tested by time and international experience. 


\section{Results}

Active innovation activity across the country will be maintained only if the innovations market is constantly updated. This is due to the fact that the capital market and competition of economic entities to one degree or another already exist. However, with the existing potential we cannot say now that we have a large arsenal of competitive and promising innovations. When developing an innovative infrastructure, special attention should be paid to the cultivation and support of research teams aimed at creating "seed" innovative enterprises. This task can be effectively solved only by ITC-type structures that can provide monitoring and assistance to startup companies in their own region, for example, as is done in Cambridge — which is a leader in the creation of science parks and innovation centers. (Zeschky, et. al. 2011).

In other words, the state, when implementing an innovation strategy, should, first of all, expand the existing ITCs or infrastructure objects similar to them in functional properties, around which, as they develop, clusters of innovations in various industry segments will self-form. Innovation and technology centers are able to effectively perform the role of the core in high-tech sectoral corporate clusters, concentrating all the key competencies that are necessary for the renewal and growth of the innovative activities of the national economy.

The formation and development of sectoral clusters is inextricably connected with the creation of a modern sectoral infrastructure. Currently, there is a gap in the chain of production and industrial development of new knowledge. On the one hand, small business has concentrated in itself the most promising innovations, but is limited in production resources to bring them to the market. On the other hand, the industrial sector has free production capacity, but does not risk investing in those innovations that have not proven their viability in the market, which limits the arsenal of possible products for industrial production (Buse, et. al. 2010).

Thus, within the framework of high-tech sectoral clusters, an experimental infrastructure must be present, through which innovations are prepared for implementation into industrial production. The experimental infrastructure serves as the foundation for the cooperation of small business, education and industry in corporate clusters. Such cooperation solves the problem of the lack of proven innovations in the market at large industry enterprises, significantly reducing the risks of introducing new high-tech products into mass production (Spiesberger, 2018).

Own resources of industrial enterprises are focused on the expansion of production, and the resources of hightech companies on the development of new types of innovative products. The experimental infrastructure of a corporate cluster is a means for producing small batches of new innovative products, which are subsequently tested on the market and, if successful, transferred to large-scale production (Fig. 1). 


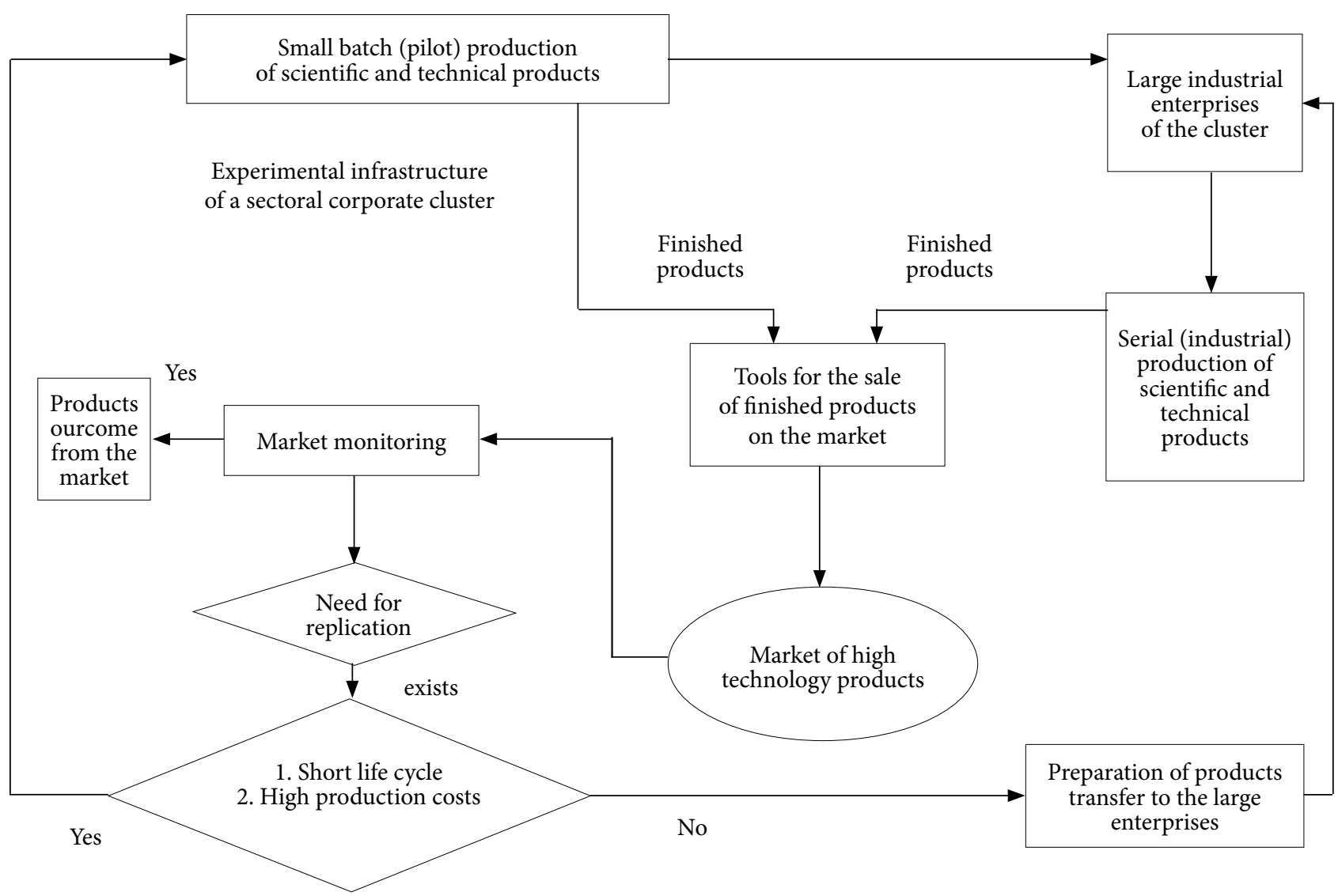

Fig. 1. Ensuring the security of the activities of the experimental infrastructure of the corporate cluster

Source: Designed by the authors

In addition, the experimental infrastructure attracts new innovation carriers to the corporate cluster, with which new investors, strategic partners, suppliers of materials, components and related services come. Thus, the experimental infrastructure is the basis for establishing system links in the corporate cluster, which provides an accelerated transfer of intellectual resources to the real economy.

However, each new stage of security and development of the experimental infrastructure of the corporate cluster must be scientifically and economically justified. On the one hand, the lack of infrastructure resources impedes the launch of new innovative projects, and on the other hand, the possible underutilization of infrastructure entails unjustified investments and additional costs. In this regard, the process of a cluster infrastructure formation should be project-oriented. In other words, the experimental infrastructure of the sectoral corporate cluster should primarily be built during the implementation of specific innovation projects and for specific developments. (Davis, et. al. 2009).

Since ITC is the center of attraction for innovation and concentrates the potential for loading the industrial sector, it is advisable to form an experimental infrastructure in its composition (Fig. 2). Moreover, ITC possesses the capabilities for project-oriented filling of the material and technical base of the cluster experimental infrastructure, realizing the package principle of promoting innovative projects.

The performance of the ITC within the cluster is determined by the quality of the internal cluster management. In a cluster, initial prerequisites should be created for establishing a system-oriented interaction between small business entities and industry-oriented scientific and educational institutions. At the same time, the question of not only how to ensure cooperation in a cluster, but also how to create the necessary synergy of intra-cluster interaction, comes to the first place. A cluster is not always an idyllic gathering of enterprises where any update is automatically stimulated. It happens that innovation processes are suppressed in clusters and protective be- 
havior is encouraged (Balitskiy, et. al. 2014). Relationships with suppliers can stimulate innovation processes, but they can also be used to shift the costs to partners and ignore their financial interests. In the latter case, the clusters are unstable and unsustainable.

Innovative development can be defined as a set of relations arising in the course of a targeted increase in the economic efficiency and competitiveness of a firm on the basis of innovations. Innovative development is a way that is based on deepening the combination of the goals of the enterprise, its subsystems, the goals of each individual that works in a team, improving its activities, improving business processes with a purpose to achieve common strategic goals (Gulda, et. al. 2016).

The strategy of innovative development of an enterprise can be defined as a set of actions and methods of conducting innovation activity that provides competitive advantages through the development and implementation of innovations. In general, the innovation strategy of an enterprise (strategy of innovation activity) can be described as a certain logical structure, on the basis of which the enterprise solves the main tasks facing it in the innovation sphere of activity. It should be take into account that both for each innovation, and for each product (service) produced there are strictly individual strategies and tactics. At the same time, a comprehensive vision of the innovation activity of an enterprise includes both specific strategies and various aspects of the production and implementation of innovations. In addition, you should give a realistic assessment of the costs and benefits of innovation in the enterprise.

The general strategic positions of the innovation activity of an enterprise are specified in the innovative development programs, which provide for the development of tactical measures to achieve the goals defined in the innovation strategy of the enterprise. An innovative program is a set of innovative processes and activities agreed upon in terms of resources, performers and timelines for their implementation, which provide an effective solution to the tasks of mastering and spreading fundamentally new types of products or technologies.

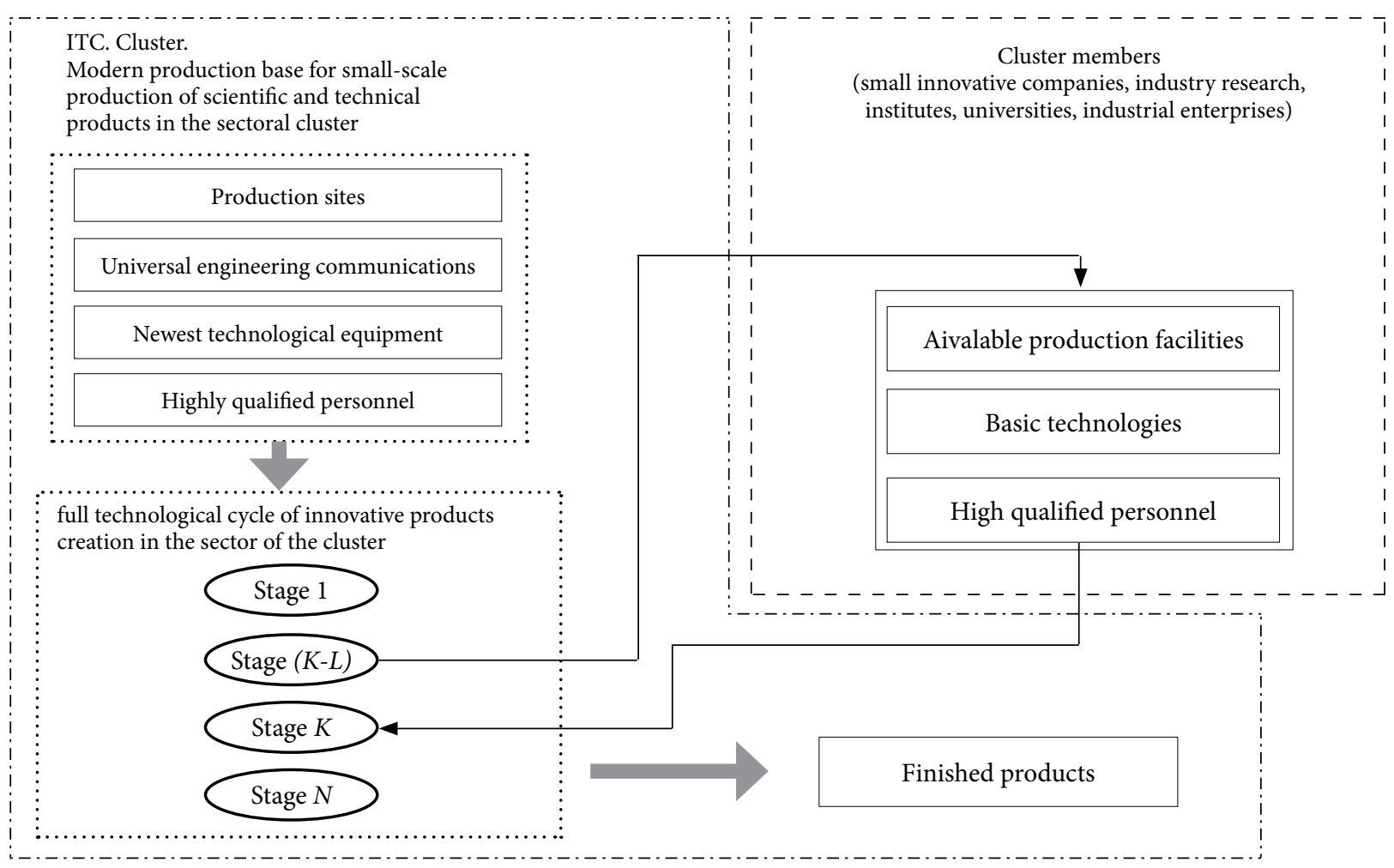

Fig. 2. Mechanism of using resources and shaping the security of the existence of cluster members to build a cluster industry infrastructure 
The model of management of innovative development and security of the enterprise is presented in Figure 3.

This model consists of six blocks, each of which has its own tasks. I want to draw attention to the main tasks. At the first stage of innovative development planning, it is necessary to evaluate the existing innovation position of the company. Management needs to determine the type of strategy to develop a company.

The next stage of innovative development planning. If the strategy of innovative development has not yet been determined, it is assumed that it can be formulated on the basis of internal analysis. However, the best solution would be to create an innovative development strategy based on internal analysis and analysis of environmental factors (Li, and Kozhikode, 2009).

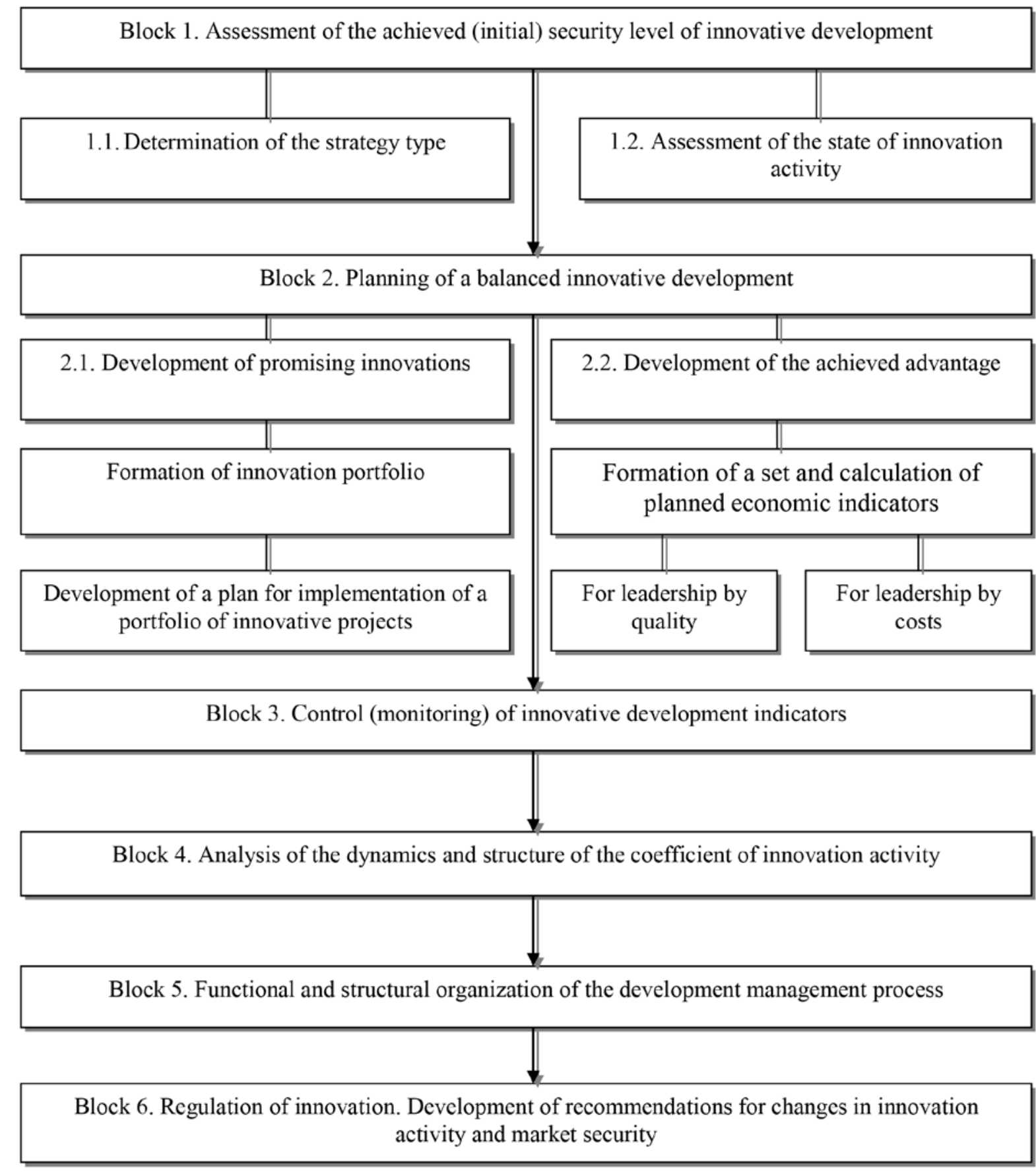

Fig. 3. Model of management of innovative development and security of the enterprise 
We will define the above two strategies: cost leadership and quality leadership. Different competitive strategies of leadership are characterized by a different ratio of unit costs and prices of products. In particular, the cost leadership strategy provides for the release of a relatively inexpensive product with low unit costs, and the quality leadership strategy is more expensive, but with higher unit costs (Table 1).

Table 1. Main characteristics of cost and quality leadership strategies

\begin{tabular}{|c|l|l|l|}
\hline $\begin{array}{c}\text { Competitive } \\
\text { strategy }\end{array}$ & \multicolumn{1}{|c|}{ Required skills and resources } & \multicolumn{1}{|c|}{ Organizational elements } & \multicolumn{1}{c|}{ Risks } \\
\hline $\begin{array}{c}\text { Cost } \\
\text { leadership }\end{array}$ & $\begin{array}{l}\text { Significant capital expenditures and access } \\
\text { to capital; } \\
\text { Engineering skills } \\
\text { Control over employees; } \\
\text { Products that can be produced on a large } \\
\text { scale; } \\
\text { Efficient distribution network. }\end{array}$ & $\begin{array}{l}\text { Cost management system; } \\
\text { Frequent, detailed reporting; } \\
\text { tructuring responsibilities and } \\
\text { distribution of powers, clear } \\
\text { regulation; } \\
\text { Innovation based on the } \\
\text { achievement of rigorous } \\
\text { quantitative goals. }\end{array}$ & $\begin{array}{l}\text { Technological changes that can set } \\
\text { to zero the investments made; } \\
\text { Lown cost imitation strategy by } \\
\text { competitors; } \\
\text { Inability to notice market changes } \\
\text { due to the great attention } \\
\text { paid to cost management; } \\
\text { Cost inflation that blurs the } \\
\text { organization's cost advantage. }\end{array}$ \\
\hline $\begin{array}{c}\text { Quality } \\
\text { leadership }\end{array}$ & $\begin{array}{l}\text { Strong marketing; } \\
\text { Products production; } \\
\text { Creative skills; } \\
\text { Skills in basic research; } \\
\text { Reputation of the organization as a } \\
\text { technology leader; } \\
\text { Long presence in the industry or unique } \\
\text { skills achieved in other industries. }\end{array}$ & $\begin{array}{l}\text { Coordination between functional } \\
\text { units - R \& D, production, } \\
\text { marketing } \\
\text { More qualitative than quantitative } \\
\text { assessment of investments; } \\
\text { A creative atmosphere that can } \\
\text { attract scientists, researchers, etc. }\end{array}$ & $\begin{array}{l}\text { Price difference is valued } \\
\text { by customers more than } \\
\text { differentiation; } \\
\text { Reducing customer differentiation } \\
\text { needs; } \\
\text { Competition imitation strategy } \\
\text { nullified product differentiation. }\end{array}$ \\
\hline
\end{tabular}

Source: Designed by the authors

The leadership strategy by quality implies more intensive growth, receiving a price premium in comparison with competitors at the expense of special competencies in order to meet the needs of consumers.

The leadership strategy by costs implies achieving low unit costs compared to competitors, which means having special cost management skills (Mahdjour, and Fischer, 2014; (Makedon, V.; Drobyazko, S.; etc., 2019). As it was noted earlier, a cost leadership strategy and a quality leadership strategy can be a strategy for corporate innovation. To do this, let's build a table of the main characteristics of leadership strategies in terms of costs and quality, but with indicators aimed at innovative development.

The leadership strategy by quality, which is focused on innovative development, is aimed at primacy in the development of new products, which is an indispensable condition for obtaining a price premium in competitive markets; therefore, the indicator of innovation activity and the innovation cycle time become the main indicators of the effectiveness of innovative management. Such a strategy is focused on high innovative activity of the corporation and speed in the implementation of new ideas through significant investments in R\&D (Rivza, and Kruzmetra, 2017).

The leadership strategy by costs, which is focused on innovative development, is aimed at the effective use of invested funds, so the main indicator of the assessment is the deviation of the actual indicators of innovative budgets from the planned. Within the framework of such a strategy, a corporation is likely to follow the path of a "follower" behind organizations that have long been on the market, and its innovative activity will be aimed at reducing costs and increasing business efficiency.

The main goal of innovation planning and development security is to assess the achievement of certain specific performance indicators. At the same time, the annual plans of this activity lay down certain indicators by months. It is advisable to determine the main objectives of the innovative program of enterprise development. They are as follows:

determination of trends in the development of scientific and technological progress in specific directions of 
the enterprise activity;

organization of enterprise development management;

determination of directions of innovation that are promising;

assessment of the effectiveness of innovative processes;

determination of risks arising in the process of creating and using innovations and their assessment;

development of projects for the introduction of innovations;

formation of innovation management system;

creation of a favorable innovation climate, as well as conditions for the organization's adaptation to innovations;

making decisions aimed at stimulating innovative activity of the organization;

justification of innovative decisions in conditions of uncertainty and risk.

It is necessary to determine the conditions under which it is advisable to form an innovative program. If the costs of implementing individual innovation projects are greater than the costs of implementing the same projects, but combined into a program. For example, the costs of eliminating staff resistance will be lower for a program than for all projects separately.

If the implementation of an innovative program can provide a higher and sustainable economic effect than the implementation of individual projects. That is, if such a distribution of projects in time is possible, which ensures a continuous flow of funds. In this case, the decline in the profitability of individual projects is compensated by the growth in the profitability of other innovative projects.

To ensure the expected results of the implementation of innovative programs, careful management is required. The subjects of management of the innovative program of enterprise development are (Ebrahim, et. al. 2010; Virta, et. al. 2017):

enterprise owners (determine development strategy);

top-level managers (execute plans for implementing strategies);

management personnel of the enterprise (performs technical work, which consists in preparing project documentation, conducting feasibility studies of projects, making forecasts of changes in supply and demand in the markets of raw materials and finished products, creating cost estimates and implementing innovative programs, etc.);

staff or freelancers engaged in R \& D (accumulate innovative ideas, study ideas for feasibility and the possibility of their implementation, create prototypes of innovative products and technologies, participate in the preparation of innovations in production, study the possibilities of their improvement and modernization); performers of individual works on innovative programs (ensure receipt of the expected results of R \& D in a timely manner, as well as prevent leakage of confidential information about the scientific achievements of the enterprise to competitors);

investors, lenders, insurers, etc. (they can be involved in innovative programs both at the stage of the formation of innovative ideas and at the stage of their implementation with a view to risk sharing).

At the present stage of economic development, many enterprises give preference not to process, but to product innovations. First, product innovations pay off more quickly than process innovations, and this is important in the context of limited funds. Secondly, with the help of product innovations, the product range is expanded, which is one of the most effective methods for increasing competitiveness in the domestic market. In general, the process of selecting innovative projects for the formation of an innovative enterprise program is quite complex and requires a certain sequence of implementation. 


\section{Discussion}

We offer the following algorithm for the formation of an infrastructure development program and the introduction of product innovations.

Stage 1. Pre-selection of innovative projects among those available in the enterprise. At this stage it is necessary to analyze the quality indicators of the projects. To do this, you can analyze, for example, the level of products novelty. In addition, it is also necessary to assess the estimated demand for new products. This stage is necessary in order to reduce the cost of further analysis of innovative projects, since the evaluation of performance indicators is a time consuming and lengthy process, and also requires a large amount of information related not so much to the project, but to the company's activities. In addition, the need for pre-selection for the degree of novelty is due to the fact that the heads of departments are tempted to include in the innovative program of the company and to receive funding for outdated and ineffective projects.

Stage 2. Analysis of the main characteristics of each innovation project. At this stage, each project from the set of alternatives should be analyzed. At the same time, the resources required for the implementation of an innovative project, the project's profitability and the level of risk are estimated.

Stage 2.1. Assessment of the need for resources for the implementation of an innovative project. It is necessary to analyze the resources available in the company, as well as the resources necessary for the implementation of the project, and then compare them. Otherwise, the lack of resources at any stage of the implementation of an innovative project may cause the project to be terminated or completely stopped. Therefore, it is the resources that act as one of the limitations in the selection of innovative projects in the company's program. In the proposed algorithm, innovative projects for which the company does not have enough resources are excluded from the selection.

Stage 2.2. Predictive assessment of profitability and risk of an innovative project. Profitability and risk are assessed according to established indicators. Projects with unsatisfactory values of the selected indicators are excluded.

Stage 3. Matching and comparison of the obtained characteristics of the projects under consideration and the formation of the program. you should choose of the projects that have passed on the indicators of novelty, profitability, risk, those from which the innovative program of the company will be formed. There may not be enough funds for the simultaneous implementation of all selected projects in the company, so the program should include those projects that will allow you to get the optimal combination of return-risk indicators. The relation of these indicators should be carried out by top management.

At the stage of forming an innovative program, it is proposed to use the following methodology: the calculation of indicators of profitability and risk for programs with various combinations of innovative projects with the subsequent comparison of these indicators by the choice of a program with the optimum ratio of the rate of return to risk. The proposed algorithm for comparing potential projects allows you to create an effective innovative program of the company. If the company has the necessary resources, the basic innovative program can be supplemented with new innovative projects that can improve the average effectiveness of the program.

\section{Conclusions}

Thus, taking into account the above, it is possible to determine the presence of the necessary attributes of an effectively functioning sectoral corporate cluster:

high level of concentration of innovation carriers (small innovative companies, research institutes) and industrial potential, in accordance with industry characteristics;

availability of modern industry experimental infrastructure for the development of innovations in smallscale production; 
sources of training qualified specialists for the industry segment of the cluster; possibility of creating innovation and technology centers, as the basis for attracting innovations and investments;

system of sectoral cluster organization should form a target cooperation of all its subjects so that the aggregate of market relations in the cluster forms a continuous chain between the carriers of innovations, the experimental infrastructure and industrial production.

The implementation of the project of introducing innovative measures may cause resistance to change. In order to avoid resistance or downsizing, you can make changes to include such aspects:

changes need to be introduced in certain portions, which take into account the specificity and adaptability of the enterprise (this will allow employees to adapt to the situation, bring all the innovations into a habit and then move on);

the most unpopular changes need to be introduced first (a one-time introduction of unpopular innovation, accompanied by guarantees for the level of salaries and the preservation of the new hierarchy, will allow better control of the situation).

To achieve the effectiveness of the implementation of a technical re-equipment project, it is necessary to fulfill the condition of an appropriate level of control and corrective measures. At each stage of the development and implementation of the project it is necessary to clarify the correctness of its implementation. On the basis of control, it is possible to identify the main problems and deviations from the planned actions, as well as the failure of the new equipment. In addition, all processes must be accompanied by regulatory measures. Under these conditions, it is possible to achieve the maximum effect from the introduction of innovative changes in the production structure of the enterprise.

\section{References}

Agarwal, N., Grottke M., Mishra. S and Brem, A. (2017). A systematic literature review of constraint-based innovations: State of the art and future perspectives. IEEE Transactions on Engineering Management, 64(1), 3-15.

Akhter, F. (2017). Unlocking digital entrepreneurship through technical business process. Entrepreneurship and Sustainability Issues 5(1): 36-42. https://doi.org/10.9770/jesi.2017.5.1(3)

Antanavičius, J., Christenko, A., Krūminas, P., Martinaitis, Ž., Paliokaite, A. (2017). Ex-Post Evaluation of the Ministry of Economy Instrument Inno-Vouchers LT. Impact on Business R\&D Expenditure and Summary of Final Report, Vilnius: Kuriame Lietuvos ateiti, Ūkio ministerija, Visionary Analytics.

Balitskiy, S., Bilan, Y., Strielkowski, W. (2014). Energy security and economic growth in the European Union. Journal of Security \& Sustainability Issues 4(2): 125-132. https://doi.org/10.9770/jssi.2014.4.2(2)

Brem, A. and Freitag, F. (2015). Internationalisation of new product development and research \& development: Results from a multiple case study on companies with innovation processes in Germany and India. International Journal of Innovation Management, 19(1): https://doi.org/10.1142/S1363919615500103

Buse, S., Tiwari, R. and Herstatt, C. (2010). Global innovation: An answer to mitigate barriers to innovation in small and medium-sized enterprises? International Journal of Innovation and Technology Management, 7(3): 215-227. https://doi.org/10.1142/ S0219877010001970

Chaminade, C., Lundvall, B. A., \& Haneef, S. (2018). Advanced introduction to national innovation systems. Cheltenham: Edward Elgar.

Cunningham, S. (2014). Hidden innovation: Policy, industry and the creative sector. Lanham, MD: Lexington Books.

Davidavičienė, V., Raudeliūnienė, J., Tvaronavičienė, M., Kaušinis, J. (2019). The importance of security aspects in consumer preferences in electronic environment, Journal of Security and Sustainability Issues 8(3): 399-411. http://doi.org/10.9770/jssi.2019.8.3(9)

Davis, C. H., Creutzberg, T., \& Arthurs, D. (2009). Applying an innovation cluster framework to a creative industry: The case of screenbased media in Ontario. Innovation: Management, Policy \& Practice, 11(2):201-214 http://doi.org/10.5172/impp.11.2.201

Dobele, L., Grinberga-Zalite, G., Kelle, L. (2015). Sustainable economic development: scenarios for promotion of social innovation in 
Latvia. Journal of Security and Sustainability. Issues 5(2): 149-158. http://dx.doi.org/10.9770/jssi.2015.5.2(2)

Ebrahim Ale, Ahmed S., Taha Z., Personal M., Archive R., and Lumpur K. (2010). SMEs; Virtual research and development (R\&D) teams and new product development: A literature review. International Journal of the Physical Sciences, 5(7), 916-930.

Felt, U., Fouché, R., Miller, C. A., \& Smith-Doerr, L. (2016). The handbook of science and technology studies (4th ed.). Cambridge, MA: MIT Press.

Foege, J.N., Piening, E.P. and Salge, T. (2016). Don't get caught on the wrong foot: A resource-based perspective on imitation threats in innovation partnerships. International Journal of Innovation Management http://dx.doi.org/10.1142/s1363919617500232

Gulda, K., Bonas, G., Spiesberger, M., Funeriu, D., Heijs, F., Räim, T., Weiss, B. (2016). Peer Review Report on Moldova’s Research \& Innovation System, Brussels: European Commission. Available at: https://rio.jrc.ec.europa.eu/en/library/horizon-2020-policy-supportfacility-peer-review-moldovan-research-and-innovation-system

Hartley, J. (2015). Urban semiosis: Creative industries and the clash of systems. International Journal of Cultural Studies, 18(1), 79-101

Kraus, S., Brem, A., M. Schuessler, and Niemand, T. (2016). Innovative born globals: Investigating the influence of their business models on international performance. International Journal of Innovation Management. http://dx.doi.org/10.1142/S1363919617500050

Li, J. and Kozhikode, R.K. (2009). Developing new innovation models: Shifts in the innovation landscapes in emerging economies and implications for global R\&D management. Journal of International Management, 15(3), 328-339.

Liu, Y. and Shi, Y. (2017). Understanding international product strategy in multinational corporations through new product development approaches and evolution. International Journal of Innovation Management, 1750057.

Mahdjour, S. and Fischer, S. (2014). International corporate entrepreneurship with born global spin-along ventures - A cross-case analysis of telekom innovation laboratories' venture portfolio. International Journal of Innovation Management, 18(3). http://dx.doi. org/10.1142/S1363919614400076

Makedon, V., Valikov V., Kurinnaya I., Koshlyak E. (2019). Strategic innovative development of the enterprises: theory and methodology, Scientific Journal Economics and Finance, issue 2: 52-62.

Makedon, V.; Drobyazko, S., Shevtsova, H., Maslosh, O., Kasatkina, M. (2019). Providing security for the development of high-technology organizations, Journal of Security and Sustainability Issues 8(4): 1313-1331. https://doi.org/10.9770/jssi.2019.8.4(18)

Mansell, R. (2012). Imagining the internet: Communication, innovation, and governance. Oxford: Oxford University Press.

Monni, S., Palumbo, F., Tvaronavičienė, M. (2017). Cluster performance: an attempt to evaluate the Lithuanian case. Entrepreneurship and Sustainability Issues, 5(1), 43-57. https://doi.org/10.9770/jesi.2017.5.1(4)

Oganisjana, K., Svirina, A., Surikova, S., Grīnberga-Zālīte, G., Kozlovskis, K. (2017). Engaging universities in social innovation research for understanding sustainability issues. Entrepreneurship and Sustainability Issues, 5(1), 9-22. https://doi.org/10.9770/jesi.2017.5.1(1)

Petrenko, Y., Vechkinzova, E., Antonov, V. (2019). Transition from the industrial clusters to the smart specialization of the regions in Kazakhstan. Insights into Regional Development, 1(2), 118-128. https://doi.org/10.9770/ird.2019.1.2(3)

Rivza, B., Kruzmetra, M. (2017). Through economic growth to the viability of rural space. Entrepreneurship and Sustainability Issues, 5(2), 283-296. https://doi.org/10.9770/jesi.2017.5.2(9)

Spiesberger, M., Gomez, J., Seigneur, I. (2018). Smart specialisation and social innovation: from policy relations to opportunities and challenges. Evidence from six case studies on clean energy regional initiatives (JRC Technical Report. S3 Policy Briefs Series 24/2018), Brussels: European Commission.

van Dijck, J., Poell, T., \& de Waal, M. (2018). The platform society: Public values in a connective world. New York, NY: Oxford University Press.

Virta, S., \& Lowe, G. F. (2017). Integrating media clusters and value networks: Insights for management theory and research from a case study of Mediapolis in Finland. Journal of Management \& Organization, 23(1): 2-21.

Von Hippel, E. (2005). Democratizing innovation. Cambridge, MA: MIT Press.

Zeschky, M., Widenmayer, B. and Gassmann, O. (2011). Frugal Innovation in emerging markets: The case of mettle. Research-Technology Management, 54(4), 38-45. 
Žižka, M., Hovorková Valentová, V., Pelloneová, N., Štichhauerová, E. (2018). The effect of clusters on the innovation performance of enterprises: traditional vs new industries. Entrepreneurship and Sustainability Issues, 5(4), 780-794. http://doi.org/10.9770/ jesi.2018.5.4(6)

Natalya G. METELENKO, Doctor of Economic Sciences, Professor, Head of the Department Finance, Banking and Insurance, Engineering Institute of Zaporizhzhya National University

ORCID ID: orcid.org/0000-0002-6757-3124

Olena V. KOVALENKO, Doctor of Sciences in Economics and Management, Professor, Director of the Dnipropetrovsk ScientificResearch Institute of Forensic Examinations

ORCID ID: orcid.org/0000-0002-6802-7213

Vyacheslav MAKEDON, Dr. Hab. (Economics), Associate Professor, Oles Honchar Dnipro National University

ORCID ID: orcid.org/ 0000-0001-8131-0235

Yevhenii K. MERZHYNSKYI, PhD in Economics, Department of economics and information technologies, Zaporizhzhya National University Engineering Institute

ORCID: ID: orcid.org/0000-0002-4372-889X

Alla I. RUDYCH, PhD in Economics, Associate Professor of Department of Accounting, Poltava state agrarian academy ORCID ID: orcid.org/0000-0002-5416-4508

Register for an ORCID ID:

https://orcid.org/register

This work is licensed under the Creative Commons Attribution International License (CC BY).

http://creativecommons.org/licenses/by/4.0/ 